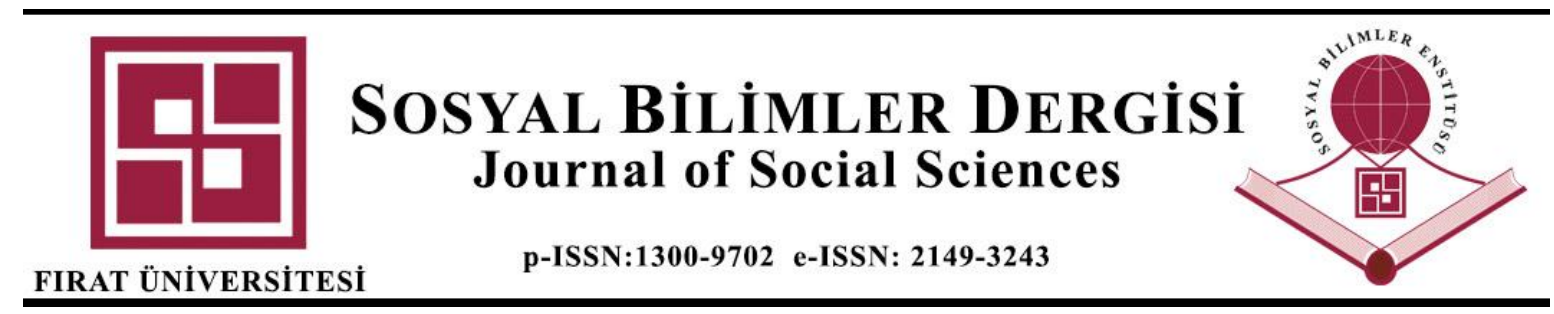

\title{
FARSÇANIN TÜRKIYY'DE \\ YABANCI DİL OLARAK ÖĞRETIMIINDE YALANCI KÖKTEŞLİK (İran Farsçası ve Türkiye Türkçesi Örneklemi)
}

\section{False Cognates In Teaching Persian As A Foreign Language In Turkey (Iranian Persian and Turkey Turkish Sample)}

\section{İsmail SÖYLEMEZ ${ }^{1}$}

Dr. Öğretim Üyesi, İönü Üniversitesi, Yabancı Diller Yüksekokulu, Farsça Birimi, Malatya, ismail.soylemez@inonu.edu.tr, orcid.org/0000-0001-7000-3686

Araştırma Makalesi/Research Article

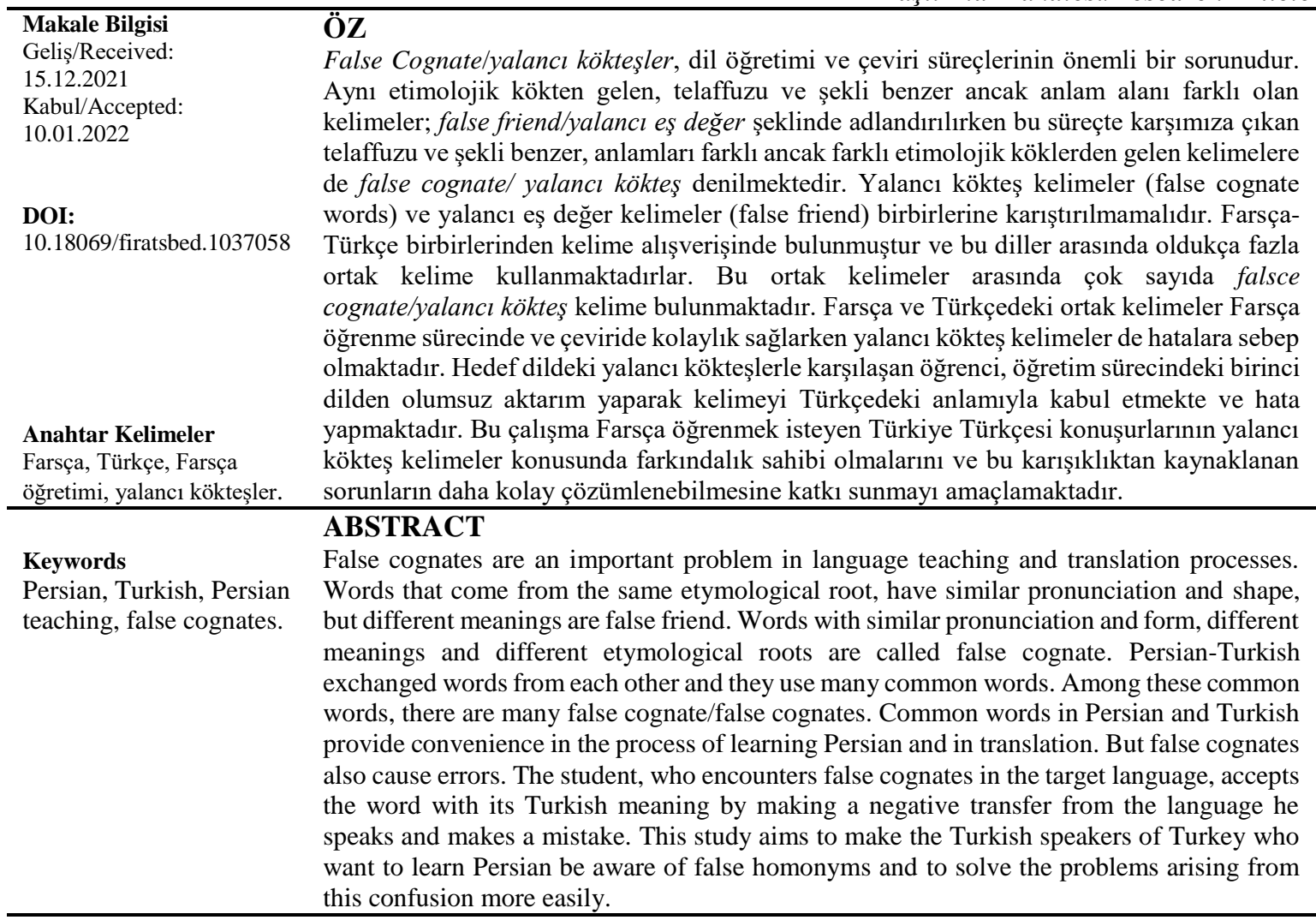

Atıf/Citation: Söylemez, İ. (2022). Farsçanın Türkiye'de Yabancı Dil Olarak Öğretiminde Yalancı Kökteşlik (İran Farsçası ve Türkiye Türkçesi Örneklemi). Firat Üniversitesi Sosyal Bilimler Dergisi, 32, 1 (69-82).

Sorumlu yazar/Corresponding author: İsmail SÖYLEMEZ, ismail.soylemez@inonu.edu.tr 


\section{Giriş}

Farsça ve Türkçe arasında tarihî ve köklü bir ilişki vardır. Dil öğretiminde diller arasındaki münasebet ve ortak kelimelerin hedef dil öğrenimini kolaylaştırdığı bilinmektedir. Bu anlamda Farsça ve Türkçe arasındaki ortaklığın da Farsça öğrenmeye başlayan Türkçe konuşurları için kolaylık sağladığı düşünülmektedir. Ancak bu kelime alışverişi sadece iki dil arasında olmamakta bazen üçüncü dillerden de kelime alınmaktadır. FarsçaTürkçe ortak kelime havuzunda Farsçadan Türkçeye geçmiş altı bin civarında kelime ve Türkçeden Farsçaya geçmiş iki bin civarında kelimenin var olduğu söylenmektedir. (Dilberipur 1995: 10; Türkben Aydın 2017: 1233) TDK Türkçe sözlüğü ise Farsçadan Türkçeye geçen 1374 kelime olduğunu, Türkçeden Farsçaya da 3000 kelime geçtiğini söylemektedir (Dursunoğlu 2009: 132) Bu tespitler genel olarak Türkçe-Farsça dil ilişkisine dairdir ancak mevcut çalışmalar Farsça-Türkçe dil ilişkisinde İran Farsçası ve Türkiye Türkçesini merkeze almaktadır. Afganistan ve Tacikistan Farsçası da değerlendirilmeye katılırsa ve başta Arapça ve Fransızca olmak üzere diğer dillerden hem Farsçaya hem de Türkçeye geçen kelimeler değerlendirmeye alınırsa iki dilin ortak kelime sayısının daha fazla olduğu görülür.

Farsça-Türkçe dil ilişkisindeki etkileşimin dil öğrenim sürecini kolaylaştırmanın yanı sıra hata riski de dikkat çekmektedir. Bu risklerin başında da false friend denilen yalancı eş değer kelimeler ve false cognate denilen yalancı kökteş kelimeler gelir. Dil öğrenicisini yanıltan bu kelimeler, metnin anlaşılmasını zorlaştırmakta ve çeviri hatalarına yol açmaktadır. Yazılışları ve telaffuzları aynı olan, aynı etimolojik kökten gelen ancak anlamları farklı olan kelimelere yalancı eş değer (false friend) denmektedir. Yalancı eş değer kelimeler, aynı kökten gelmelidir.

Sesteş kelimeler de denilen yalancı kökteş kelimeler (false cognate) ise farklı köklerden gelen ve aynı şekilde telaffuz edilen kelimelerdir. Yalancı eş değer kelimeler ve yalancı kökteş kelimeler karıştırılmamalıdır zira her iki kelime grubu da şekil ve telaffuz olarak benzer olup her iki dilin söz varlığında yer almaktadır. Yalancı kökteş kelimelerin temel farkı, köken itibariyle farklı dillerden veya aynı dilin farklı kelime kökünden gelmeleridir. Yani yalancı kökteş kelimeler farklı kökten olmalıdır. Kökenleri aynı olan kelimelere de yalancı eş değer denmektedir (Özeren, 2014: 9). Yalancı eş değerliğe örnek olarak Arapçadan Farsça ve Türkçeye geçmiş olan adi/عادى kelimesi verilebilir. Adi, ar.<far.(normal), adi, ar.<tr.(bayă̆gl, de ğersiz) şeklinde farklı anlamlar ifade etmektedir. Farsça ve Türkçedeki yalancı eş değer kelimeler hakkında ayrıntılı bilgi için Türkiye'de Yabancı Dil Olarak Farsça Öğretiminde Yalancı Eş Değerlik (İran Farsçası ve Türkiye Türkçesi Örneklerimi (Söylemez, 2021) başlıklı çalışmaya bakılabilir. Yalancı kökteşliğe ise Farsçadaki baxt/ ياخت, far. (yenilgi, mağlubiyet) ile Türkçedeki baht, ar.<tr. (şans, talih) kelimeleri örnek olarak verilebilir..

Türkçe ve Farsçadaki yalancı kökteşlerin değerlendirildiği bu çalışmada İran Farsçası esas alınmıştır. Literatür taramasında Afganistan ve Tacikistan Farsçası ve Türkçe ile ilişkileriyle ilgili herhangi bir kaynağın tespit edilememesi, saha deneyiminin olmaması nedeniyle çalışma sınırlılığına dahil edilmemiştir. Bu çalışmada beş yıl boyunca İran deneyimi döneminde sahadan derlenen kelimelerin yanı sıra, İ.Ü. Farsça kurslarındaki Farsça öğretimi sürecinde derlenen ve ayrıca iki dildeki Büyük Türkçe Sözlük, Ferhengê Emid gibi temel sözlüklerin taranmasıyla elde edilen İran Farsçası ile Türkiye Türkçesindeki yalancı kökteş kelimeler tasnif edilmiştir. Daha sonra bu yalancı kökteş kelimelerin Türkiye Türkçesi konuşuru olan öğrencilere Farsçanın yabancı dil olarak öğretimi sürecindeki etkileri, öğrencilerin ödev ve sınav kâğıtlarına uygulanan hata incelemesi ile elde edilen veriler üzerinden değerlendirilmiştir. Bu çalışma, İran Farsçası ile Türkiye Türkçesi arasındaki yalancı kökteş kelimeler hakkında bir veri ve farkındalık oluşturmayı, Türkiye Türkçesi konuşuru olan dil öğrenicisinin yalancı kökteş kelimelerde konuştuğu dilden yapacağı olumsuz aktarımları önleyebilmeyi amaçlamaktadır.

\section{Türkiye'de Yabancı Dil Olarak Farsça Öğretimi}

Selçuklu döneminden itibaren Anadolu coğrafyasında Farsçaya yönelik bir ilgi her zaman olagelmiştir. Osmanlı ve ardından Türkiye coğrafyasında geçmişten günümüze dek çeşitli seviyelerde ve mahfillerde Farsçanın yabancı dil olarak öğretiminin çeşitli kurumlar tarafindan veya özel gayretlerle sürdürüldüğü bilinmektedir. Tanzimat döneminden itibaren Farsça ilk ve orta dereceli okulların neredeyse tamamında, yüksekokulların da bir bölümünde öğretilen belli başlı yabancı dillerden birisi olmuştur (Çelik 2005: 3). Üniversitelerde ise müstakil anabilim dalı olarak 1935'ten beri Farsça öğretimi yapılmaktadır. Ankara Üniversitesi 1935, İstanbul Üniversitesi 1938, Atatürk Üniversitesi 1968, Selçuk Üniversitesi 1975, Kırıkkale Üniversitesi 1992 (Turgut 2011: 83; Çelik 2005: 36,41), Artuklu Üniversitesi 2015 tarihinde Farsça öğretimine 
başlamıştır. Ayrıca Edebiyat, Fen-Edebiyat, İlahiyat ve Eğitim Fakülteleri ile Yüksek İslam Enstitüleri (Çelik, 2005: 270) olmak üzere çok sayıda fakülte ve bölümde Farsça öğretimi yapılmaktadır. MEB'e bağlı İHL'lerde 1971'e kadar Farş̧a öğretimi yapılmıştır (Çelik, 2005: 280; Şimşekler, 2021: 33). Ardından 2017 yllında MEB'e bağlı, devlet okulları ve özel okullar ile özel kurslarda Farsça öğretimine izin verilmiştir (www.mevzuat.gov.tr: 04.10.2021).

\section{Yalancı Kökteşlik}

Yalancı kökteşlik, İngilizce false cognate olarak, Farsçada ise eş değer görünümlü anlamındaki

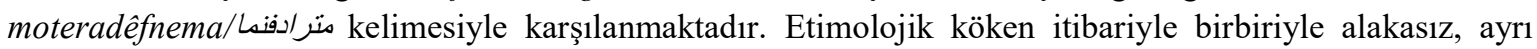
köklerden ve hatta ayrı dillerden olmalarına rağmen yer aldığı dillerdeki modern formu itibariyle aynı şekilde yazılan (bazen küçük yazım farkı da olabilir) ve aynı şekilde telaffuz edilen kelimelere false cognatelyalancı kökteş denilmektedir.

Literatürde yalancı kökteşlere ait tanımlara bakıldığında; Housman, yalancı kökteşleri/false cognates biçimsel benzerliklerine rağmen farklı anlamlara sahip farklı dillerdeki kelime çiftlerini ifade eden terimler (Routledge, 1996: 163) şeklinde tanımlarken Richards, şekil olarak birbirine benzeyen, ancak farklı anlamlar ifade eden farklı dillerdeki kelimeler şeklinde tanımlamaktadır (Richards, 1992: 136). Aksan da yalancı kökteşliği, yalancı sesteşlik olarak isimlendirmekte ve farklı anlamda olan iki veya daha fazla kelimenin, zamanla geçirdiği ses veya biçim değişikliği sonucu birbirine yaklaşarak sesteş duruma gelmesi veya alıntı bir kelimenin, yerli dilde var olan bir başka kelime ile seslik bakımdan benzer olması (Aksan 2016: 92-93) şeklinde tanımlamaktadır. David Crystal (2010), iki dilde yazılışları birbirine benzeyen ancak aynı anlamı taşımayan sözcükleri sahte benzerlik/faux amis olarak tanımlar (Bermaganbetova, 2016:40).

Cognate/kökteş kelimeler aynı kökene sahip ve yazılışları, okunuşları ve anlamları benzerlik gösteren kelimeler (Erkır, 2011: 17) iken false cognatelyalancı kökteşler ise anlam ve köken itibariyle farklılaşan kelimelerdir. Bazı çalışmalarda yazılış ve söylenişi benzer olan, köken ve kavram alanları farklı olan sesteş kelimelerin yalancı eş değer olarak ifade edilmişse de bunun doğru olmadı̆̆ını söylemek mümkündür. Bu kelimelerin yalancı eş değerlerden tamamen farklı olmaları nedeniyle yalancı kökteş olarak isimlendirilmesi ve bu şekilde değerlendirilmesi daha doğru olacaktır.

Literatür taramasında Türkiye'de Farsça-Türkçe dil ilişkisindeki yalancı kökteş kelimeleri inceleyen bir çalışma tespit edilememiştir ancak farklı dil ilişkilerinin yanı sıra Türkçe ve diğer dillerdeki yalancı kökteşlik konusunun incelendiği görülmüştür. İngilizce merkezli yapılan Horst, White ve Bel (2010)'in çalışması yabancı dil öğrenme sürecinden anadilden yararlanma odaklı bir çalışmayken, Barker ve Sutcliffe (2000), İngilizce ile Lehçe dil ilişkisini incelemiştir (Erkır, 2011: 23). Mohammad Reza Piruz (2003) ise İngilizceFarsça dil ilişkisindeki yalancı kökteşleri çalışmıştır. Türkiye'de de Asker Resulov (1995) yalancı eş değer kelimeleri çalışan ve yalancı kökteş kelimeler ile farkını açıklayarak, karıştırılmamasını vurgulayan ilk araştırmacı olarak dikkat çekmektedir. Yine Erkır (2011) ile Uzun ve Salihoğlu (2009)'nun İngilizce-Türkçe dil ilişkisi odaklı yalancı kökteş kelimeler konulu çalışmaları önemlidir.

Yalancı kökteş kelimeler ve ilgili çalı̧̧malar diller arası yalancı kökteşler ve dil içi yalancı kökteşler olarak iki başlık altında toplanabilir. Bu çalışmada diller arası ve kaynak dil içi yalancı kökteşlik kapsamında Farsça ve Türkçedeki yalancı kökteş kelimeler incelenecektir.

\section{Farsça-Türkçe Dil İliş̧kisinde Yalancı Kökteşlik}

Farsça ve Türkçedeki yalancı kökteş kelimeler, sınıf içi etkinliklerde verilen anlık çeviri görevlerinde, edebî çevirilerde ve zaman zaman da çeşitli sözlü çeviri ortamlarında Farsçadan Türkçeye ve Türkçeden Farsçaya yapılan çevirilerde oluşan hatalarla sıklıkla karşımıza çıkmaktadır. Bu hatalar diller arası çevirinin de eksik veya yanlış olmasına yol açmaktadır. Yalancı kökteşlik durumunun ortaya çıkmasının temel sebebinin ise dil öğrenicisinin veya çevirmenin konuştuğu dilden olumsuz aktarım yapması olduğu görülmektedir. Zira öğrenci veya çevirmen yalancı kökteş bir kelimeyle karşılaş̧ı̆̆ında şekil ve telaffuz itibariyle benzer veya aynı olan kelimenin konuştuğu dilde de olması nedeniyle ilk anda konuştuğu dildeki kelimeyi hatırlamakta ve bu da onu hataya sevk etmektedir.

$\mathrm{Bu}$ çalışmada değerlendirmeye tabi tutulan veriler araştırmacının İran'da bulunulan beş yıllık deneyim süresince sahadan derlenmiş kelimelerden, İ.Ü. Farsça kurslarındaki Farsça öğretimi sürecinde sahadan 
derlenen kelimelerden ve Farsça ile Türkçenin temel sözlüklerinin taranmasıyla elde edilen kelimelerden oluşmaktadır. Farsça ve Türkçe dil ilişkisinde 214 kelime çifti, toplam 428 yalancı kökteş kelime tespit edilmiştir. Çalışmada tespit edilen bu 214 kelime çifti yani 428 kelime etimolojik köken itibariyle tasnif edilerek listelenmiş ve değerlendirilmiştir.

Farsça ve Türkçedeki yalancı kökteş kelimeler incelendiğinde karşımıza etimolojik köken itibariyle Farsça, Türkçe, Arapça, Fransızca, Ingilizce, Italyanca, Soğdca ve Yunanca dillerinden gelen kelime grupları çıkmaktadır. Tespit edilen yalancı kökteş kelimelerden 175 kelime çiftinin, 350 kelimenin diller arası yalancı kökteş ve 39 kelime çiftinin yani 78 kelimenin de dil içi yalancı kökteş kelime olduğu görülmektedir.

\subsection{Farsça-Türkçe Dil İlişkisinde Diller Arası Yalancı Kökteşlik}

Farklı dillerden geçen haliyle farklı etimolojik kökten gelen ancak modern formu itibariyle şekil ve telaffuzu birbirine benzer veya birbirinin aynısı ve anlam alanları farklı olan kelimeler diller arası yalancı kökteş kelimeler olarak kabul edilmektedir.

Diller arası yalancı kökteşlik, iki dil arasında dört ayrı şekilde karşımıza çıkmaktadır. Dil ilişkisinde karşılaşılan yalancı kökteş kelimelerin söz konusu iki dilin söz varlığından olması zorunlu değildir. Her iki dilin ayrı ayrı başka bir dilden ödünçlediği kelimelerde de yalancı kökteşlik durumu ortaya çıkabilir. Nitekim Farsça-Türkçe dil ilişkisini incelediğimiz bu çalışmada Farsça ve Türkçe dışında Arapça, Fransızca, Ingilizce, Italyanca, Soğdca ve Yunanca olmak üzere altı yabancı dilden kelimelerin her iki dile geçerek yalancı kökteşlik oluşturduğu görülmektedir. Bu çalışmada tespit edilen 175 diller arası yalancı kökteş kelime çiftinin 98'i Farsça ve Türkçe kökenli iken 77'si de diğer dillerden her iki dile geçmiş ve yalancı kökteşlik oluşturmuş kelimelerdir. $\mathrm{Bu}$ tespitler doğrultusunda diller arası yalancı kökteş kelimeler kanaatimizce;

a) İncelemeye konu iki dil arasında kelime alışverişi olmadan, her iki dilin kendi söz varlığındaki kelimelerin yalancı kökteş olması,

b) İki dil arasındaki ilişkide tespit edilen kelimelerden birinin incelemeye konu dillerden birinin kendi söz varlığından olması ve diğer kelimenin ise üçüncü bir dilden karşı dile geçerek yalancı kökteş olması,

c) Her iki dildeki kelimelerin kendi söz varlıklarından olmayıp üçüncü ve dördüncü yabancı dillerden bu dillere geçerek yalancı kökteş olması,

d) İncelemeye konu iki dilden biri kökenli bir kelimenin üçüncü yabancı dilden gelen bir kelimeyle yalancı kökteş kelime durumuna düşmüş olması şeklinde dört grup halinde incelenebilir. Bu sınıflandırma önerisinin konunun daha rahat anlaşılmasına katkı sağlayacağı düşünülmektedir.

Birinci grupta; Farsça ve Türkçe dil ilişsisinde herhangi bir kelime alışverişi olmadan, her iki dilin kendi söz varlığında diğer dilin söz varlığındaki bir kelimeyle aynı veya benzer bir kelimenin bulunması ve dil karşılaşması esnasında yalancı kökteş kelime durumuna düşmesi şeklinde ortaya çıkmaktadır. Bu gruba Türkçe ve Farsçadaki dana/Lłdana kelime çifti örnek olarak gösterilebilir. Bu örnekteki ne Türkçe dana kelimesi Farsçaya geçmiştir ne de Farsçadaki dana kelimesi Türkçeye geçmiştir. Bu kelime çifti dil ilişkisinin başlamasıyla birlikte yalancı kökteş kelime durumuna düşmüştür.

İkinci grupta; Farsça ve Türkçe dil ilişkisinde iki dil arasındaki kelime alışverişi sırasında dilden dile geçen kelimelerin geçtiği dilde yalancı kökteşlik oluşturması şeklinde olmaktadır. Bu gruba Farsça ve Türkçe dil ilişkisinde dilden dile ödünçleme yapılan bă̆/bă̆ ve kar/kar kelime çiftleri örnek olarak gösterilebilir.

Üçüncü grupta; incelemeye konu olan her iki dile üçüncü ve dördüncü dillerden gelerek karşılıklı bir şekilde yalancı kökteşlik oluşturması şeklindedir. Bu duruma Farsça-Türkçe dil ilişsisinde her iki dilin söz varlığına dışarıdan gelerek dâhil olmuş olan Arapça-Fransızca harp/harp ve ray/ray kelime çiftleri örnek olarak verilebilir.

Dördüncü grupta; incelemeye konu olan dil çiftinde bulunan dillerden biri kökenli bir kelimenin üçüncü yabancı dilden bu dil çiftine geçen bir kelimeyle yalancı kökteşlik oluşturması durumudur. Bu gruba FarsçaFransızca kökenli berê/bere kelime çifti örnek olarak gösterilebilir. Bere kelimesi Fransızca olup külah anlamında iken, berê kelimesi de Farsça olup kuzu anlamındadır. 


\subsubsection{Farsça-Türkçe Dil İlișkisinde Farsça-Türkçe Yalancı Kökteș Kelime Çiftleri}

Farsça-Türkçe dil ilişkisinde 215 yalancı kökteş kelime çifti tespit edilmiştir. 215 kelime çiftindeki 430 yalancı kökteş kelimeden 98 kelime çiftindeki 197 kelime Farsça-Türkçe dil ilişkisi kökenlidir. Bu grupta alandaki yaygın kabule uyularak Pehlevice ve Farsça ayrımı yapılmamıştır.

Farsça-Türkçe yalancı kökteş kelime çiftlerinden anca/anca, abi/abi, as/as, asan/asan kelime çiftlerinde görüldügü üzere kelimeler arasında şekil ve telaffuz açısından tamamen bir örtüşme görülürken anlam ve etimolojik köken itibariyle kelimeler arasında ilişki yoktur.

Farsça-Türkçe yalancı kökteş kelime çiftlerinden ablê/abla, ard/art, arayêş/arayış, ari/arı, ayêş/ayaş kelime çitlerinde görüldüğü üzere alfabe farkı kaynaklı küçük bir şekil ve ses farklılığı görülmektedir. Örneklerin incelenmesinden de görüleceği üzere Farsça-Türkçe dil ilişkisindeki yalancı kökteş kelimelerin tamamı isim soylu kelimelerdir.

\begin{tabular}{|l|c|}
\hline Ben dağ çayını seviyorum. (Y) & من جاى داغ را دوست دارم. \\
\hline Ben sicak çayı seviyorum. (D) & Men çayê daq ra dust darem. \\
\hline
\end{tabular}

Örnek cümledeki $\dot{\xi} \nvdash$ ydağ kelimesi Farsçada sıcak, yakıcı anlamında kullanılan bir kelime olup Farsça kökenli iken yalancı kökteşi durumundaki dağ kelimesi ise Türkçe bir kelime olup yeryüzünün çıkıntıll, yüksek, eğimli yamaçlarıyla geniş alana yayılan bölümü anlamında kullanılır. Görüldüğü üzere Türkçedeki dă̆ kelimesinin Farsçadaki $d a \breve{g}$ kelimesiyle köken ve anlam itibariyle herhangi bir ilişkisi yoktur. Bu iki kelime sadece şekil ve telaffuz olarak benzeşmekte, bu da yalancı kökteşlik oluşturmaktadır.

\begin{tabular}{|l|c|}
\hline O, abinin kitabını götürdü. (Y) & U kêtabê abi ra bord. \\
\hline O, mavi kitabı götürdü. (D) & أبرد 1 (D) \\
\hline
\end{tabular}

Örnek cümledeki abi kelimesi Farsça kökenli olup mavi renk anlamında kullanılırken yalancı kökteşi durumundaki abi kelimesi ise Türkçe bir kelime olup büyük erkek kardeş anlamındadır. Her iki kelime köken olarak birbirinden bağımsız ancak şekil ve telaffuz olarak birbirlerine benzedikleri için yalancı kökteşlik oluştururlar (Tablo 1).

Tablo 1. Farsça-Türkçe Dil İlişkisinde Farsça-Türkçe Yalancı Kökteş Kelimeler

\begin{tabular}{|c|c|c|c|c|}
\hline $\begin{array}{l}\text { Kelimenin } \\
\text { Farsça } \\
\text { Telaffuzu } \\
\end{array}$ & $\begin{array}{l}\text { Kelimenin } \\
\text { Farsça } \\
\text { Yazılışı } \\
\end{array}$ & Kelimenin Farsçadaki Anlamı & $\begin{array}{l}\text { Kelimenin } \\
\text { Türkçe } \\
\text { Telaffuzu } \\
\end{array}$ & Kelimenin Türkçedeki Anlamı \\
\hline Abi & آبى (20) & Mavi & Abi & Ağabey \\
\hline Ablê & آبله & Çiçek hastalığı, uçuk & Abla & Büyük kız kardeş \\
\hline Acor & آجز & Tuğla, kiremit & Acur & Çizgili ve tüylü yeşil bir meyve \\
\hline Ăger & آغز & Kuru nehir sel yatağı & A & Hafif olmayan \\
\hline Ağol & آغول & Ahır & Oğul & Erkek evlat \\
\hline Anca & آنجا & Ora, orasi & Anca & Ancak \\
\hline Arayêş & آرايش & Süs, süsleme, makyaj & Arayıș & Arama işi \\
\hline Ard & ارد & Un & Art & Arka \\
\hline Ari & آرى & Ari ırkına mensup olan & Arı & Zar kanatlı, eklem bacaklı ucan böcek \\
\hline As & 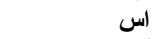 & Değirmen, değirmen taşı & As & As1l olan, birincil \\
\hline As & 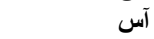 & Değirmen değirmen taşı & As & As1l, esas \\
\hline Asa & آسنا & Süs & Asa & Baston, değnek \\
\hline Asan & آسان & Kolay, rahat & Asan & Asma işini yapan \\
\hline Ay & آى & Ey, hey, vah, vay & Ay & İlenme sözcüğü, y1lın on iki bölümü \\
\hline Ayêş & آيش & Geliş & Ayaș & İçkiye düşkün, çok içki içen \\
\hline $\mathbf{A z}$ & آز & Hirs, heves, gam & Az & Çok olmayan \\
\hline Azar & آزار & Eziyet, sıkıntı, işkence & Azar & İkaz, uyarı, kınama \\
\hline Azma & آزما & Deneyen, sinayan & Azma & Azmak, azış \\
\hline Bak & 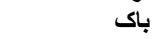 & Korku & Bak & Bakmaktan emir, gör \\
\hline Bala & بالا & Yüksek, üst & Bala & Çocuk, yavru \\
\hline Baq & باغ & Bahçe; park & Băğ & İp, şerit, tel vb bağlama aracı; deste \\
\hline Barêş & بارش & Yağı̧⿻ & Barıș & Barışma işi \\
\hline Basêq & باسث & Yüksek, uzun & Basık & Basılmış, alçak, kısık \\
\hline Bayêr & باير & Kıraç & Bayır & Yokuş aşağı \\
\hline Bêçem & بقإم & Düzenli, kuralı, süslenmiş & Biçem & Üslup, içerik \\
\hline Belut & بلوط & Palamut & Bulut & Gökyüzündeki su buharı \\
\hline Beq & بغ & Tanrı, yaratıcı & Beg/Bey & Reis, şef, soylu kişi \\
\hline Besi & بسى & Çok & Besi & Besleme işi, hayvan besleme \\
\hline Beș & بش بش & Kilit, kuru ziraat & Beș & Dörtten sonraki rakam \\
\hline Bid & بيا & Söğüt ağacı & Bit & Asalak bir böcek \\
\hline
\end{tabular}




\begin{tabular}{|c|c|c|c|c|}
\hline Binêş & بينش & Görüş, bak1ş & Biniş & Binme işi \\
\hline Bir & بير & Yatak; kuyu & Bir & Sayıların ilki; aynı, benzer \\
\hline Boz & بز & Keçi & Boz & Açık toprak rengi \\
\hline Bu & بو & Koku & Bu & Yakını gösteren işaret sıfatı \\
\hline Capa & جإِا & Ayak izi & Çapa & Çapalama işi ve aleti \\
\hline Çap & جابٍ & Bask1, tabetme & Çap & Ebat, cismin genişliği \\
\hline Çarpa & جاريا & Yük hayvanı, eşek & Çarpı & Kaba sıva, çarpma \\
\hline Çay & جاى & Yapraklarından içecek yapılan bitki & Çay & Dereden büyük, ırmaktan küçük akarsu \\
\hline Çêle & جله & Zahmet, s1kıntı & Çile & İpek, yün, pamuk vb. iplik demeti \\
\hline Dalan & 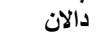 & Dehliz, koridor; kapalı yol; han & Dalan & Dalma işini yapan \\
\hline Dam & دام & Tuzak, kapan, pusu, evcil hayvan & Dam & Çatı, toprak çatılı ev \\
\hline Dana & دانا & Bilge, bilgin, âlim & Dana & İnek yavrusu \\
\hline Daq & 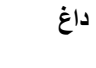 & Kavurucu, yakıcı, sıcak & Dăg & $\begin{array}{l}\text { Yeryüzünde çıkıntılı, yüksek, eğimli } \\
\text { bölüm }\end{array}$ \\
\hline Dar & دار & Darağacı; ağaç; kavak & Dar & Geniş olmayan, bol olmayan \\
\hline Daş & 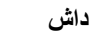 & Kabadayı & Taş/Daş & Katılaşarak oluşmuş çok sert bir cisim \\
\hline Daver & داور & Hakem, jüri & Davar & Koyun veya keçi sürüsü \\
\hline Demar & دمار & $\begin{array}{l}\text { Et sakatatı; işkence etme, canına } \\
\text { okumak }\end{array}$ & Damar & Kanın dolaştığı kanal \\
\hline Deri & 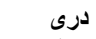 & Sarayla ilgili, saray Farsçası & Deri & Vücudun dış yüzeyi, cilt \\
\hline Duş & 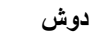 & Dün gece & Döş & Göğüs, bağır \\
\hline Duş & دوش & Dün gece & Düş & Hayal \\
\hline Duşêş & 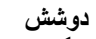 & Sağım, sağma & Düşüş & Düşme \\
\hline Engel & انكل & Parazit & Engel & Mani \\
\hline Gaz & كاز & Isırma & Gaz & Cismin üç halinden biri \\
\hline Gebr & كبر & Zerdüşti; Mecusi; kâfir & Geber & Öl anlaminda beddua \\
\hline Gelê gelê & كلة كلة & Yer yer, öbek öbek & Güle güle & iyi dilek sözü \\
\hline Genc & كنج & Define, hazine & Genç & Yaşlı olmayan \\
\hline Girêş & كيرش & Tutma, yakalama & Giriş & Girme yeri \\
\hline Girêşgah & كيرشگاه & Yakalama yeri; tutacak & Girizgâh & Konu açmak için söylenen söz \\
\hline Givê & كيوه & İplik dokuma ayakkabı & Güve & Yünlü kumaş ve dokuma yiyen böcek \\
\hline Kabuk & كابوى & Kuş yuvası & Kabuk & Bir şeyin üstünü kaplayan sert tabaka \\
\hline Kaş & كاش & Keşke & Kaş & Göz üstünde kavis şekilli kısa kıllar \\
\hline Kiz & كيز & Darlık; kısa adım; büzülme & Kız & Dişi evlat \\
\hline Kol & كل & Kısa; eksik; ağır & Kol & Organ $\operatorname{ad}_{1}$ \\
\hline Kolê & كله & Kısa; eksik & Köle & Savaşta esir düşen \\
\hline Kulak & كولاك & Firtına; tipi & Kulak & İşitme organı \\
\hline Kur & كور & Kör & Kor & Ateş haline gelmiş odun ve kömür \\
\hline Kuz & كوز & Kambur & Köz & Kızıl ateş parçası, kor \\
\hline Omac & 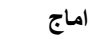 & Küçük hamur topu & Amaç & Hedef, gaye \\
\hline Pas & باس & Güvenlik, koruma & Pas & Demir ve metallerde oksitlenme \\
\hline Pay & لِّاى & Ayak & Pay & Hisse, eşit bölüm \\
\hline Saqer & سناغر & Kadeh & Sağır & Duymayan \\
\hline Sal & 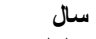 & Y1l, sene & Sal & Küçük bir su taşıtı \\
\hline Saman & 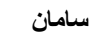 & Düzen & Saman & Hayvan yemi \\
\hline Sari & 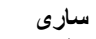 & Siğırcık & Sarı & Bir renk \\
\hline Sel & سل - ال & Sal; kılıç çekme & Sel & Su taşkını \\
\hline Soru & سرو & Boynuz; böcek anteni & Soru & Sual \\
\hline Sorun & سرون & Boynuz & Sorun & Problem \\
\hline Su & سو & Yön, taraf & Su & İçilen sıv1 \\
\hline Suçê & سوجه & Koltuk altı bezi & Suç & Kabahat \\
\hline Şaş & شاش & İdrar, sidik & Şaşı & Gözleri aynı yere bakmayan \\
\hline Şaşu & شاثو & Altına işeyen & Şaşı & Gözleri şaşı bakan \\
\hline Taban & 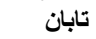 & Berrak, parlak & Taban & Ayakla basılan zemin \\
\hline Tabêş & 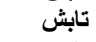 & Parlayış, parıltı & Tapış & Tapma \\
\hline Tapu & تايو & Küçük toprak kap & Tapu & Mülkiyet gösterir belge \\
\hline Tarik & تاريك & Karanlık & Tarik & Yol \\
\hline Tas & طاس & Kel & Tas & Sulu yemek konulan metal kap \\
\hline Taşek & ت تاشك & Tereyağı; süzme yoğurt & Taşak & Er bezi \\
\hline Tavan & 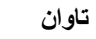 & Zarar, ziyan & Tavan & Odanın üst yüzü \\
\hline Tay & 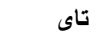 & Bir, tek, denk & Tay & At yavrusu \\
\hline Tepêş & 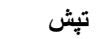 & Huzursuzluk, titreme, & Tepiş & Tepme \\
\hline Terek & 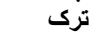 & Çatlak & Terek & Raf \\
\hline Ters & 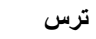 & Korku & Ters & Zit, huysuz \\
\hline Tevan & 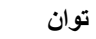 & Güç, kuvvet & Tavan & Odanın üst yüzü \\
\hline Tiz & تيز & Sivri, ince & Tez & Çabuk olan, süratli \\
\hline Tupal & تويال & Talaş & Topal & Aksak \\
\hline Yazêş & يازش & Kasıt; yönelmek & Yazış & Yazma \\
\hline Yelê & يله & Bırakma, saçma & Yele & Aslan, at vb. hayvanların ense kılı \\
\hline Yex & يخ & Buz & Yağ & Meyve veya çekirdeğinin sıvısı \\
\hline
\end{tabular}




\subsubsection{Farsça-Türkçe Dil İlişkisinde Farsça-Arapça Yalancı Kökteş Kelime Çiftleri}

Farsça-Türkçe dil ilişkisinde tespit edilen 214 kelime çiftindeki 428 kelimeden 22 kelime çiftindeki 44 kelime Farsça-Arapça dil çiftinin etkileşimi sonucu oluşmuş yalancı kökteş kelimelerdir. Tespit edilen bu yalancı kökteş kelime çiftleri Farsça-Türkçe dil ilişkisinde Arapçanın her iki dili etkilemesi ve kelime vermesi bağlamında Türkçe tarafında Farsça dil öğrenicisinin karşısına çıkmaktadır. Bu kelimeler Arapçadan Farsçaya geçerek Farsça asıllı kelimelerle yalancı kökteş durumuna düşmüştür. Bu gruba, acil/acil, merdane/merdane, baht/baxt kelimeleri örnek olarak verilebilir (Tablo 2).

Faşça merkezli hazırlanan kelime listesinde tablonun ilk iki sütununda Farsça kelimenin telaffuzu, yazılışı ve Farsçadaki anlamı verilmiştir, tablonun dördüncü ve beşinci sütununun da Arapçadan Türkçeye geçmiş ve Farsça-Türkçe dil ilişkisinde yalancı kökteşlik oluşturmuş kelimeler verilmektedir.

Tablo incelendiğinde bu kelimelerin tamamının isim soylu kelimeler olduğu görülecektir. Bu incelemede diller arası geçişkenliği olan fiil soylu bir kelime tespit edilememiştir.

\begin{tabular}{|l|c|}
\hline Ben acil satın aldım. (Y) & من آجيل خريدم. \\
\hline Ben çerez satın aldım. (D) & Men acil xeridem. \\
\hline
\end{tabular}

Örnek cümledeki بيل/acil kelimesi Farsça olup kuruyemiş, çerez anlamındadır. Yalancı kökteşi durumundaki Acil ise Arapça olup Türkçede hemen yapılması gereken, ivedi anlamındadır.

\begin{tabular}{|l|c|}
\hline O mağaza kadın elbisesi ve merdane satıyor. (Y) & آن فروشكاه لباس زنانه و مردانه مى فروشد. \\
\hline O mağaza kadın elbisesi ve erkek elbisesi satıyor. (D) & An foruşgah lêbasê zenanê ve merdane mi foruşed. \\
\hline
\end{tabular}

Örnek cümledeki هردانها/merdane kelimesi Farsça olup erkeksi, erkeklere ait, erkek gibi anlamındadır. Yalanc1 kökteşi durumundaki merdane kelimesi Arapça olup Türkçede hamur işlerinde kullanılan kalın oklava anlamındadır.

Tablo 2. Farsça-Türkçe Dil İlişkisinde Farsça-Arapça Yalancı Kökteş Kelimeler

\begin{tabular}{|c|c|c|c|c|}
\hline $\begin{array}{l}\text { Kelimenin } \\
\text { Farsça } \\
\text { Telaffuzu }\end{array}$ & $\begin{array}{l}\text { Kelimenin } \\
\text { Farsça } \\
\text { Yazılışı } \\
\end{array}$ & Kelimenin Farsçadaki Anlamı & $\begin{array}{l}\text { Kelimenin } \\
\text { Türkçe } \\
\text { Telaffuzu }\end{array}$ & Kelimenin Türkçedeki Anlamı \\
\hline Acil & أجيل & Kuruyemiş & Acil & $\begin{array}{l}\text { Hemen, anında; hastanenin acil } \\
\text { bölümü }\end{array}$ \\
\hline Ema & اما & Lakin & Âmâ & Kör \\
\hline Amud & آمود & Yapıl1, süslenmiş & Amud & Dik durma \\
\hline Baxt & 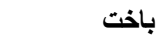 & Mağlubiyet & Baht & Şans, talih \\
\hline Bazi & 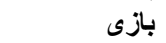 & Oyun & Bazı & Bir kısmı, ara sıra \\
\hline Bikar & 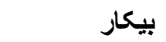 & İşsiz & Bekâr & Evlenmemiş \\
\hline Bina & بينا & Gören & Bina & Yap1 \\
\hline Borc & 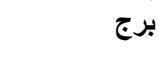 & Ay; yüksek bina & Burç & $\begin{array}{l}\text { Kale duvarındaki yüksek çıkıntı; } \\
\text { takımyıldız adı }\end{array}$ \\
\hline Darabi & 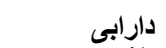 & Greyfurt & Daraba & Kepenk \\
\hline Efgar & افقًار & Yaralı & Efkâr & Hüzün, düşünce \\
\hline Hal & 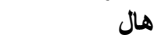 & Sessizlik & Hal & Durum \\
\hline Has & 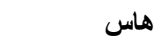 & Diğer; dahi, korku & Has & Özgü \\
\hline Hemsal & 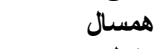 & Akran, yaşit & Emsal & Benzer, eş \\
\hline Kabilê & كابيله & Havan, taş havan & Kabile & Sülale \\
\hline Kanun & كانون & Kurum; merkez & Kanun & Yasa \\
\hline Kasten & 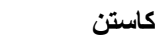 & Eksiltmek, azaltmak & Kasten & Bilinçli olarak, bilerek \\
\hline Kulê & كوله & Yük, bir taşımalık yük & Kule & Kare, silindir yüksek yap1 \\
\hline Lal & لال & Dilsiz & Lal & Parlak kırmızı değerli bir taş \\
\hline Merdanê & مردانه & Erkeksi, erkekle ilgili & Merdane & Kalın oklava \\
\hline Nalê & ناله & İnleyiş & Nal & Hayvan tırnaklarına çakılan demir \\
\hline Nar & نار & Ateş & Nar & Bir meyve \\
\hline Resen & 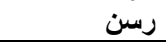 & Urgan; yular & Resen & Kendi başına, kendiliğinden \\
\hline
\end{tabular}




\subsubsection{Farsça-Türkçe Dil İlişsisinde Arapça-Türkçe Yalancı Kökteş Kelime Çiftleri}

Farsça-Türkçe dil ilişkisinde, Arapça-Türkçe etkileşimi neticesinde oluşmuş 11 yalancı kökteş kelime çiftinde 22 adet yalancı kökteş kelime tespit edilmiştir. Bu grupta tespit edilen Arapça kökenli kelimeler Farsçada kullanılmakta olup Farsça-Türkçe dil ilişkisinde Farsça söz varlığı içerisinde dil öğrenicisinin karşısına çıkmaktadır. $\mathrm{Bu}$ kelimeler, Türkçedeki benzer kelimelerle yalancı kökteşlik oluşmasına sebebiyet vermektedirler. Bu gruba; soluk/soluk, yeqin/yakın, qap/kap, qapan/kapan gibi kelime çiftleri örnek olarak verilebilir (Tablo 3).

\begin{tabular}{|c|c|}
\hline Bir grup yakın yolda şüpheye düşmüş. $(\mathrm{Y})$ & قومى به كمان افتاده در راه يقين \\
\hline Bir grup kesin bilgi yolunda şüpheye düşmüş. (D) & Qowmi bê goman oftadê der rahê yeqin \\
\hline
\end{tabular}

Örnek cümledeki يقينyeqin kelimesi Arapça olup Farsçada kesin bilgi, doğrulanmış bilgi anlamındadır. Bu kelimenin yalancı kökteşi yakın kelimesi ise Türkçe olup uzak olmayan, akraba anlamındadır.

\begin{tabular}{|c|c|}
\hline Etin soluğu çok tehlikelidir. (Y) & صلوك كُشت خيلى خطرناك است. \\
\hline Etin çürüğü çok tehlikelidir. (D) & Solukê guşt xeyli xeternak est. \\
\hline
\end{tabular}

Örnek cümledeki صلوكى/soluk kelimesi Arapça olup Farsçada çürümüş, kokuşmuş et anlamındadır. Bu kelimenin yalancı kökteşi soluk Türkçe olup nefes, hava, ciğerlere hava alıp verme anlamındadır.

Tablo 3. Farsça-Türkçe Dil İlişkisinde Arapça-Türkçe Yalancı Kökteş Kelimeler

\begin{tabular}{|c|c|c|c|c|}
\hline $\begin{array}{l}\text { Kelimenin } \\
\text { Farsça } \\
\text { Telaffuzu }\end{array}$ & $\begin{array}{l}\text { Kelimenin } \\
\text { Farsça } \\
\text { Yazılışı } \\
\end{array}$ & $\begin{array}{l}\text { Kelimenin Farsçadaki } \\
\text { Anlamı }\end{array}$ & $\begin{array}{l}\text { Kelimenin } \\
\text { Türkçe } \\
\text { Telaffuzu }\end{array}$ & Kelimenin Türkçedeki Anlamı \\
\hline Al & آل & Aile, soy & Al & Kirmiz1 \\
\hline Aşêq & 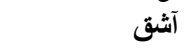 & Çok seven & Aşık & Topuğun iki yanındaki kemik \\
\hline Bel & بِل & Aksine & Bel & Sırtla kalça arasındaki bölüm \\
\hline Qanêt & قانط & Ümitsiz, üzgün & Kanit & Delil \\
\hline Qap & قابٍ & Aş1k kemiği & Kap & S1v1, katı madde konan şey \\
\hline Qapan & قِان & Kantar, baskül & Kapan & Tuzak \\
\hline Qari & قارى & Okuyucu; Kur'an okuyan & Karı & Eş, yaşlı kadın \\
\hline Soluk & صلوى & Etin çürümesi ve kokması & Soluk & Nefes; solmuş \\
\hline Şura & شورا & Danışma & Şura & Şu yer \\
\hline Tabur & 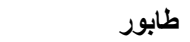 & Sira, saf & Tabur & Binbaşı komutasındaki birlik \\
\hline Terk & ترى & Ayrilma & Terek & Raf \\
\hline Yeqin & 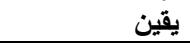 & Kesin bilgi & Yakın & Uzak olmayan; akraba \\
\hline
\end{tabular}

\subsubsection{Farsça-Türkçe Dil İlişkisinde Arapça-Fransızca Yalancı Kökteş Kelime Çiftleri}

Farsça-Türkçe dil ilişkisinde çalışmaya konu dil çiftinin söz varlığında yer alan Arapça-Fransızca kökenli 6 kelime çifti tespit edilmiştir. Tespit edilen bu 12 kelimeden harp, koliye, ray, seri, tentene, salat Arapça kökenli iken, harp, tentene, seri, ray, kolye ve salad Fransızca kökenlidir (Tablo 4).

\begin{tabular}{|l|c|}
\hline O eşi için hastaneden bir kolye istiyor. (Y) & او براى همسرش از بيمارستان يكى كليه مى خو اهذ. \\
\hline O eşi için hastaneden bir böbrek istiyor. (D) & U berayê hemsereş ez bimarêstan yêk koliyê mi xahed. \\
\hline
\end{tabular}
Örnek cümledeki كلبه/koliye kelimesi Arapça olup Farsçada böbrek anlamındadır. Yalancı kökteşi durumundaki kolye kelimesi Fransızca olup Türkçede süs için boyna takılan takı anlamındadır.

\begin{tabular}{|l|c|}
\hline Onlar savaş öğrenmeye başladılar. (Y) & آنها شروع به آموزش هارب كردند. \\
\hline Onlar harp öğrenmeye başladılar. (D) & Anha şoru’ bê amuzêşê harp kerdend. \\
\hline
\end{tabular}

Örnek cümledeki هارب/harp kelimesi Fransızca olup Farsçada bir müzik aleti olan arp anlamındadır. Yalancı kökteşi harp ise Arapça olup Türkçede savaş anlamındadır. 
Farsçanın Türkiye'de Yabancı Dil Olarak Öğretiminde Yalancı Kökteşlik...

Tablo 4. Farsça-Türkçe Dil İlişkisinde Arapça-Fransızca Yalancı Kökteş Kelimeler

\begin{tabular}{|c|c|c|c|c|}
\hline $\begin{array}{l}\text { Kelimenin } \\
\text { Farsça } \\
\text { Telaffuzu }\end{array}$ & $\begin{array}{l}\text { Kelimenin } \\
\text { Farsça } \\
\text { Yazzlışı }\end{array}$ & $\begin{array}{l}\text { Kelimenin Farsçadaki } \\
\text { Anlamı }\end{array}$ & $\begin{array}{l}\text { Kelimenin } \\
\text { Türkçe } \\
\text { Telaffuzu }\end{array}$ & Kelimenin Türkçedeki Anlamı \\
\hline Harp & هاربٍ & Üçgen şekilli müzik aleti & Harp & Savaş \\
\hline Koliyê & كليه & Böbrek & Kolye & Gerdanlık, boyuna takılan süs \\
\hline Ray & راى - ت إى & Görüş & Ray & Tren yolu \\
\hline Salad & سالاد & Salata, tuzlu sebze & Salat & Namaz \\
\hline Seri & 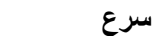 & Hızlı, çabuk & Seri & Dizi, sıra \\
\hline Tentene & طنطنه & Tantana, görkem & Tentene & Dantel \\
\hline
\end{tabular}

\subsubsection{Farsça-Türkçe Dil İlişkisinde Farsça-Fransızca Yalancı Kökteş Kelime Çiftleri}

Farsça-Türkçe dil ilişkisinde, Farsça-Fransızca 25 yalancı kökteş kelime çifti tespit edilmiştir. Bar/bar, bere/bere, kabin/kabin örneklerinde olduğu gibi Fransızca kelimeler Türkçe üzerinden Farsça öğrenicisinin karşısına çıkmakta ve yalancı kökteşlik oluşturmaktadır (Tablo 5).

\begin{tabular}{|c|c|}
\hline Ben bir barda şarap içtim. (Y) & من يك بار شراب نوشيدم. \\
\hline Ben bir defa şarap içtim. (D) & Men yêk bar şerab nuşidem. \\
\hline
\end{tabular}

Örnek cümledeki içkili ĕ̆lence yeri, salondaki içki köşesi anlamındadır.

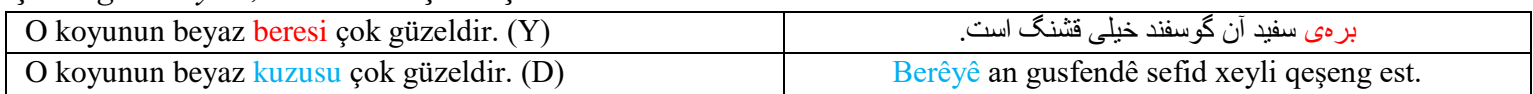
Örnek cümledeki „ـ/berê Farsça olup kuzu anlamındadır yalancı kökteşi bere Fransızca olup Türkçede külah, şapka anlamındadır.

Tablo 5. Farsça-Türkçe Dil İlişkisinde Farsça-Fransızca Yalancı Kökteş Kelimeler

\begin{tabular}{|c|c|c|c|c|}
\hline $\begin{array}{l}\text { Kelimenin } \\
\text { Farsça } \\
\text { Telaffuzu }\end{array}$ & $\begin{array}{l}\text { Kelimenin } \\
\text { Farsça } \\
\text { Yazılışı } \\
\end{array}$ & $\begin{array}{l}\text { Kelimenin Farsçadaki } \\
\text { Anlamı }\end{array}$ & $\begin{array}{l}\text { Kelimenin } \\
\text { Türkçe } \\
\text { Telaffuzu }\end{array}$ & Kelimenin Türkçedeki Anlamı \\
\hline Alu & آلو & Erik & Alo & Telefonda hitap sözcüğü \\
\hline Bar & بار & Yük; defa, kere & Bar & Dans edilen içkili eğlence yeri \\
\hline Bere & بره & Kuzu & Bere & Külah \\
\hline Erg & 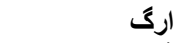 & Kale & Org & Çalgılı müzik aleti \\
\hline Far & فار & Fare & Far & Taşıtların lambası \\
\hline Gong & 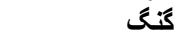 & Dilsiz, müphem & Gong & Belli zamanları bildiren zil \\
\hline Hindi & 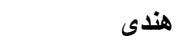 & Hintçe; Hintli & Hindi & En büyük kümes hayvanı \\
\hline Kabin & كابين & Başlık parası & Kabin & Küçük oda \\
\hline Kast & كاست & Eksiklik & Kast & Toplumsal sinıf \\
\hline Kolun & كلون & Kap1 sürgüsü & Kolon & Direk, sütun \\
\hline Kongre & كنكره & Sütun, burç & Kongre & Meclis, toplant 1 \\
\hline Kornêş & 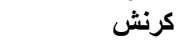 & Tevazu, eğilme & Korniş & Perde asilan alet \\
\hline Kur & كور & Kör & Kur & Kadının gözüne girmeye çalışma \\
\hline Madam & 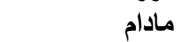 & Madem; devam eden & Madam & Evli kadın \\
\hline Mat & 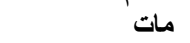 & Şaşkın, sersem, donakalmış & Mat & Parlak olmayan, donuk \\
\hline Mayê & مايه & As1l, esas; servet & Mayo & Sahilde giyilen tek parça giysi \\
\hline Merg & 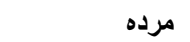 & Ölüm & Morg & Cenaze konulan soğuk ortam \\
\hline Mordê & 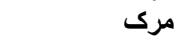 & Ölü & Mort & Ceset \\
\hline Morğ & مرغ & Kuş & Morg & Cenaze konulan soğuk ortam \\
\hline Pas & 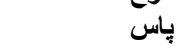 & Güvenlik, koruma & Pas & Topun takım arkadaşına ulaştırılması \\
\hline Pelas & تِّلاس & Yünden kilim & Palas & Görkemli konut, saray \\
\hline Pil & بيل & Fil & Pil & Enerji arac1, batarya \\
\hline Rot & 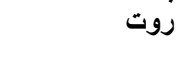 & Çıplak & Rot & $\begin{array}{l}\text { Direksiyonla tekerlek bağlantısını } \\
\text { sağlayan demir çubuk }\end{array}$ \\
\hline Tartar & تارتار & Parça parça & Tartar & Diş taş1; şarap tortusu \\
\hline Tuş & توش & Güç, kudret & Tuş & Klavyedeki düğme \\
\hline
\end{tabular}

\subsubsection{Farsça-Türkçe Dil İlişkisinde Türkçe-Fransızca Yalancı Kökteş Kelime Çiftleri}

Farsça-Türkçe dil ilişkisinde Türkçe-Fransızca kökenli eski/eski, parke/parke, kap/kap, tup/tüp şeklinde 4 kelime çifti tespit edilmiştir (Tablo 6). 


\begin{tabular}{|l|c|}
\hline Ben eski sporu çok seviyorum. (Y) & من ورش اسكى را خيلى دوست دارم. \\
\hline Ben kayak sporunu çok seviyorum. (D) & Men verzêşê eski ra xeyli dust darem. \\
\hline
\end{tabular}

Örnek cümledeki اسكسى/eski Fransızca olup Farsçada kayak sporu anlamında kullanılıyorken yalancı kökteşi eski kelimesi ise Türkçe olup yeni olmayan, yıpranmış anlamındadır.

\begin{tabular}{|l|c|}
\hline Benim iki tane kabım var. (Y) & Men do ta kap darem. \\
\hline Benim iki tane kupam var. (D) & دواب دارم \\
\hline
\end{tabular}

Örnek cümledeki Yalancı kökteşi kap kelimesi Türkçe olup içine bir şeyler konulabilen oyuk nesne anlamındadır.

Tablo 6. Farsça-Türkçe Dil İlişkisinde Türkçe-Fransızca Yalancı Kökteş Kelimeler

\begin{tabular}{|c|c|c|c|c|}
\hline $\begin{array}{l}\text { Kelimenin } \\
\text { Farsça } \\
\text { Telaffuzu }\end{array}$ & $\begin{array}{l}\text { Kelimenin } \\
\text { Farsça } \\
\text { Yazlıșı }\end{array}$ & $\begin{array}{l}\text { Kelimenin Farsçadaki } \\
\text { Anlamı }\end{array}$ & $\begin{array}{l}\text { Kelimenin } \\
\text { Türkçe } \\
\text { Telaffuzu }\end{array}$ & Kelimenin Türkçedeki Anlamı \\
\hline Eski & اسكىى & Kayak & Eski & Yeni olmayan \\
\hline Kap & كابٍ & Fincan, kupa & Kap & Sıv1 veya katı madde konan şey \\
\hline Parke & باركه & Adliye & Parke & Ahşap zemin döşemesi \\
\hline Tup & تُوبٌ & Top & Tüp & Gaz tüpü \\
\hline
\end{tabular}

\subsubsection{Farsça-Türkçe Dil İlişkisinde Farsça-Soğdca Yalancı Kökteş Kelime Çiftleri}

Farsça-Türkçe dil ilişkisinde yalancı kökteşlik oluşturan Farsça-Soğdca bir kelime çifti tespit edilmiştir. Bu kelimelerden biri Soğdcadan Türkçeye geçen borç diğeri Farsça ł borc kelimesidir (Tablo 7).

\begin{tabular}{|c|c|c|}
\hline Biz en büyü & orcun içinde yaşıyoruz. (Y) & ما در بزركترين برج زندكى مى كنيم. \\
\hline Biz en büyü & inada yaşıyoruz. (D) & Ma der bozorgterin borc zêndegi mi konim. \\
\hline $\begin{array}{l}\text { Örnek cüml } \\
\text { kelimesi Soğ }\end{array}$ & $\begin{array}{l}\text { ki łborç kelimesi Farsça olup } \\
\text { a olup Türkçede ödünç para anlam }\end{array}$ & rç, yüksek bina anlamındadır. Yalancı kökteşi bor \\
\hline & Tablo 7. Farsça-Türkçe Dil İlişkisin & sça-Soğdca Yalancı Kökteş Kelimeler \\
\hline Kelimenin & Kelimenin $\quad$ Kelimenin Farsçadaki & $\begin{array}{ll}\text { Kelimenin } & \text { Kelimenin Türkçedeki Anlamı }\end{array}$ \\
\hline Farsçadaki & Anlamı & Türkçedeki \\
\hline Telaffuzu & Yazılışı & Telaffuzu \\
\hline Borc & Ay; yüksek bina, kule & Ödünç para \\
\hline
\end{tabular}

\subsubsection{Farsça-Türkçe Dil İlişkisinde Farsça-İtalyanca Yalancı Kökteş Kelime Çiftleri}

Farsça-Türkçe dil ilişkisinde Farsça-İtalyanca kökenli barber/berber, bastan/baston, dara/dara, kase/kasa şeklinde 4 kelime çifti tespit edilmiştir. Bu kelimelerin dördü Farsça, dördü İtalyanca olup Türkçede kullanılmaktadır (Tablo 8).

\begin{tabular}{|c|c|}
\hline Berber kitapları eve götürmüş. (Y) & باربر كتاب ها را به خانه برده. \\
\hline Kargocu kitapları eve götürmüş. (D) & Barber kêtabha ra bê xanê bordê. \\
\hline
\end{tabular}

Örnek cümledeki kökteşi berber kelimesi İtalyanca olup Türkçede saç sakal tıraşı yapan anlamındadır.

\begin{tabular}{|c|c|}
\hline Bir kasa mercimeğin kaç kalorisi vardır. (Y) & يكى كاسه عدسى جقدر كالرى دارد؟ \\
\hline Bir tas mercimeğin kaç kalorisi vardır. (D) & Yêk kasê edesi çêqedr kalori dared? \\
\hline
\end{tabular}

Örnek cümledeki كاسا /kasê kelimesi Farsça olup Farsçada çömlek, çini gibi derin tabak anlamındadır. Yalancı kökteşi kasa kelimesi İtalyanca olup Türkçede sandık, kutu anlamındadır.

Tablo 8. Farsça-Türkçe Dil İlişkisinde Farsça-İtalyanca Yalancı Kökteş Kelimeler

\begin{tabular}{|c|c|c|c|c|}
\hline $\begin{array}{l}\text { Kelimenin } \\
\text { Farsça } \\
\text { Telaffuzu }\end{array}$ & $\begin{array}{l}\text { Kelimenin } \\
\text { Farsça } \\
\text { Yazılışı }\end{array}$ & $\begin{array}{l}\text { Kelimenin Farsçadaki } \\
\text { Anlamı }\end{array}$ & $\begin{array}{l}\text { Kelimenin } \\
\text { Türkçe } \\
\text { Telaffuzu }\end{array}$ & Kelimenin Türkçedeki Anlamı \\
\hline Bastan & باستان & Eski & Baston & Asa, değnek \\
\hline Dara & دارا & Sahip, zengin & Dara & Bir aracın, kabın boş ağırlı̆̆ \\
\hline Kase & كاسه & Çömlek, çini, derin tabak & Kasa & Sandik, kutu \\
\hline
\end{tabular}




\subsubsection{Farsça-Türkçe Dil İlişkisinde Fransızca-Yunanca Yalancı Kökteş Kelime Çiftleri}

Türkçe-Farsça dil ilişkisinde, Fransızca-Yunanca iki yalancı kökteş kelime çifti tespit edilmiştir. Tespit edilen bu dört kelimenin ikisi Fransızcadan Farsçaya, ikisi Yunancadan Türkçeye geçmiştir (Tablo 9).

\begin{tabular}{|l|c|}
\hline O gerçekten bir berber idi. (Y) & او و اقعا يكى بربر بود. \\
\hline O gerçekten bir barbar idi. (D) & U vaqên yêk berber bud. \\
\hline
\end{tabular}

Örnek cümledeki برberber Fransızca olup Farsçada vahşi, kültürsüz, barbar anlamındadır. Yalancı kökteşi berber Yunanca olup Türkçede saç sakal tıraşı yapan anlamındadır.

\begin{tabular}{|l|c|}
\hline O Türkiye'nin Urumiyedeki konsoludur. (Y) & او كنسول تركيه در اروميه است. \\
\hline O Türkiye'nin Urumiye konsolosudur. (D) & U konsulê Torkiye der Urmiyê est. \\
\hline
\end{tabular}

Örnek cümledeki كنسول/konsul Fransızca olup Farsçada konsolos anlamındadır. Yalanc1 kökteşi konsol Yunanca olup Türkçede üstüne ayna, süs eşyası konulan çekmeceli dolap anlamındadır.

Tablo 9. Farsça-Türkçe Dil İlişkisinde Fransızca-Yunanca Yalancı Kökteş Kelimeler

\begin{tabular}{|c|c|c|c|c|}
\hline $\begin{array}{l}\text { Kelimenin } \\
\text { Farsça } \\
\text { Telaffuzu }\end{array}$ & $\begin{array}{l}\text { Kelimenin } \\
\text { Farsça } \\
\text { Yazılışı } \\
\end{array}$ & $\begin{array}{l}\text { Kelimenin Farsçadaki } \\
\text { Anlamı }\end{array}$ & $\begin{array}{l}\text { Kelimenin } \\
\text { Türkçe } \\
\text { Telaffuzu }\end{array}$ & Kelimenin Türkçedeki Anlamı \\
\hline Berber & بريز & Vahşi, kültürsüz, barbar & Berber & Saç, sakal tıraşı yapan \\
\hline Konsul & 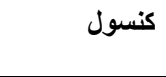 & Konsolos & Konsol & $\begin{array}{l}\text { Üstüne ayna, süs eşyası konulan } \\
\text { çekmeceli dolap }\end{array}$ \\
\hline
\end{tabular}

\subsubsection{Farsça-Türkçe Dil İlişkisinde Fransızca-İngilizce Yalancı Kökteş Kelime Çiftleri}

Farsça-Türkçe dil ilişkisinde Fransızca-İngilizce kökenli bir yalancı kökteş kelime çifti tespit edilmiştir. Kelimelerden biri Fransızcadan Farsçaya, biri İngilizceden Türkçeye geçmiştir (Tablo 10).

\begin{tabular}{|l|c|}
\hline Bu geçen seneki halidir. (Y) & اين مد إِارسال است \\
\hline Bu geçen seneki modadır. (D) & İn modê parsal est. \\
\hline
\end{tabular}

Örnek cümledeki د১/mod kelimesi Fransızca olup Farsçada moda, yeni adet anlamındadır. Yalancı kökteşi mod İngilizce olup Türkçede durum, hal anlamındadır.

Tablo 10. Farsça-Türkçe Dil İlişkisinde Fransızca-İngilizce Yalancı Kökteş Kelimeler

\begin{tabular}{lllll}
\hline $\begin{array}{l}\text { Kelimenin } \\
\text { Farsçadaki } \\
\text { Telaffuzu }\end{array}$ & $\begin{array}{l}\text { Kelimenin } \\
\text { Farsça } \\
\text { Yazılıșı }\end{array}$ & $\begin{array}{l}\text { Kelimenin Farsçadaki } \\
\text { Anlamı }\end{array}$ & $\begin{array}{l}\text { Kelimenin } \\
\text { Türkçedeki } \\
\text { Telaffuzu }\end{array}$ & $\begin{array}{l}\text { Kelimenin Türkçedeki } \\
\text { Anlamı }\end{array}$ \\
\hline Mod & L & Moda, yeni adet & Mod & Durum, hal \\
\hline
\end{tabular}

\section{2. Farsça-Türkçe Dil İlişskisinde Dil İçi Yalancı Kökteşlik}

Aynı dildeki farklı etimolojik kökten gelen ancak şekil ve telaffuz olarak birbirine benzeyen veya aynılaşan ve anlam alanları birbirinden farklı olan kelimeler dil içi yalancı kökteşler olarak kabul edilir. Bu çalışmada 38 dil içi yalancı kökteş kelime çifti tespit edilmiştir. Tespit edilenlerin 19'u Farsça olup, Farsçadaki farklı köklerden türemiştir, 48'i Arapça olup farklı kökten türemiştir. Arapçada kelimelerin bir kısmı ise aynı kelime kökünün farklı kalıplarıyla üretilmiştir. Arapçada farklı kalıplarla üretilen kelimeler aynı kökten gelseler dahi farklı anlam taşıdığı için dil içi yalancı kökteşlik bağlamında değerlendirilmiştir. İki kelime de Fransızca kökenlidir. Farsça kelimelere dadê/dadl, kah/kah, taxt/taht, Arapça kelimelere adet/aded, azêm/azim, cesad/cesed, Fransizcaya da bors/burs kelimeleri örnek verilebilir.

\subsubsection{Farsça-Türkçe Dil İlişskisinde Farsça-Farsça Yalancı Kökteş Kelime Çiftleri}

Farsça-Türkçe dil ilişkisinde 10 adet Farsça dil içi yalancı kökteş kelime çifti tespit edilmiştir. Tespit edilen kelimelerin onu Farsçadan Türkçeye geçtikten sonra, Türkçenin söz varllğı içinde yer alıyorken Farsça-Türkçe karşılaşmasında yalancı kökteş olmaktadır (Tablo 11).

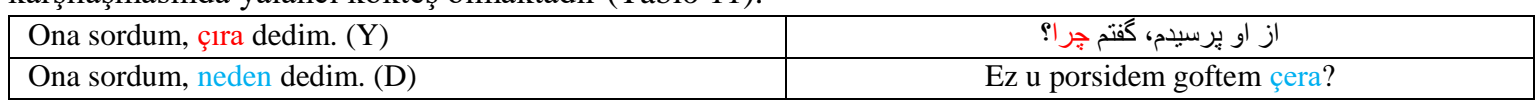

Örnek cümledeki /ج̧çera kelimesi Farsça olup niçin, neden, niye anlamındadır yalancı kökteși çıra Farsça olup Türkçede yağll ve çabuk yanan küçük parça anlamındadır. 
Tablo 11. Farsça-Türkçe Dil İlişkisinde Farsça-Farsça Yalancı Kökteş Kelime Çiftleri

\begin{tabular}{|c|c|c|c|c|}
\hline $\begin{array}{l}\text { Kelimenin } \\
\text { Farsça } \\
\text { Telaffuzu }\end{array}$ & $\begin{array}{l}\text { Kelimenin } \\
\text { Farsça } \\
\text { Yazılışı }\end{array}$ & $\begin{array}{l}\text { Kelimenin Farsçadaki } \\
\text { Anlamı }\end{array}$ & $\begin{array}{l}\text { Kelimenin } \\
\text { Türkçe } \\
\text { Telaffuzu }\end{array}$ & Kelimenin Türkçedeki Anlamı \\
\hline Çera & جرا & Niçin, niye & Çıra & Yağlı ve çabuk yanan küçük parça \\
\hline Dadê & داده & Veri, emanet & Dadı & Çocuk bakıcısı \\
\hline Dayê & دايه & Sütanne; bakıc1 & Dayı & Annenin erkek kardeși \\
\hline Hoda & هـا & Rehberlik & Hüda & Tanr1 \\
\hline Kaften & كافتن & Yarmak, kazımak & Kaftan & İpekten yapılan uzun süslü üst giysi \\
\hline Kah & كاه & Saman & Kâh & Bazen \\
\hline Pol & بپل & Köprü & Pul & Para \\
\hline Taxt & تاخت & Saldırı & Taht & Taht, padişah makamı \\
\hline Tenê & تنه & Gövde & Tane & Tek varlığı gösteren sayı birimi \\
\hline
\end{tabular}

\subsubsection{Farsça-Türkçe Dil İlişkisinde Arapça-Arapça Yalancı Kökteş Kelime Çiftleri}

Farsça-Türkçe dil iliş̧kisinde 22 Arapça dil içi yalancı kökteş kelime çifti tespit edilmiştir. Tespit edilen 48 kelimenin yarısı Farsçada yarısı Türkçede kullanılan yalancı kökteş kelimelerdir. 9 kelime ayrı etimolojik kökten türemiş, 13 kelime aynı kökün farklı kalıplarından türemiştir (Tablo 12).

\begin{tabular}{|l|c|}
\hline Ben ihbar1 okuyorum. (Y) & Men exbar ra mi xanem. \\
\hline Ben haberleri okuyorum. (D) & من اخبار رانم \\
\hline
\end{tabular}

Örnek cümledeki خبار/exbar kelimesi Arapça خبر kelimesinin çoğulu ve Farsçada haberler anlamındadır. Yalancı kökteşi durumundaki ihbar ise Arapça ancak farklı bir kalıptan türetilmiş olup Türkçede haber verme, bildirme anlamındadır.

\begin{tabular}{|c|c|}
\hline Bunlar öğrencilerin cezveleridir. (Y) & اين ها جزوههاى دانشجو ها استند. \\
\hline Bunlar öğrencilerin ders notlarıdır. (D) & İnha cozvêyê danêşcuha estend. \\
\hline
\end{tabular}

Örnek cümledeki Arapça جزوcozvê kelimesi Farsçada not, ders notu, kitapçık anlamındadır. Yalancı kökteşi cezve ise Arapça farklı bir kökten türemiş olup Türkçede kahve pişirilen saplı küçük kap anlamındadır.

Tablo 12. Farsça-Türkçe Dil İlişkisinde Arapça-Arapça Yalancı Kökteș Kelimeler

\begin{tabular}{|c|c|c|c|c|c|}
\hline $\begin{array}{l}\text { Kelimenin } \\
\text { Farsça } \\
\text { Telaffuzu } \\
\end{array}$ & $\begin{array}{l}\text { Kelimenin } \\
\text { Arapça } \\
\text { Yazılışı } \\
\end{array}$ & $\begin{array}{l}\text { Kelimenin Farsçadaki } \\
\text { Anlamı }\end{array}$ & $\begin{array}{l}\text { Kelimenin } \\
\text { Türkçe } \\
\text { Telaffuzu }\end{array}$ & $\begin{array}{l}\text { Kelimenin } \\
\text { Arapça } \\
\text { Yazılışı }\end{array}$ & Kelimenin Türkçedeki Anlamı \\
\hline Adet & عادت & Alışkanlık & Aded & عدد & Tane, sayı \\
\hline Azêm & 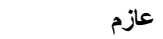 & Yola çıkan, yolcu & Azim & 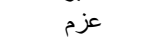 & Çaba, gayret \\
\hline Cesad & 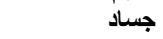 & Safran & Ceset & جسد & Ölü beden, naaş \\
\hline Corm & 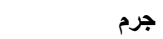 & Suç, cürüm & Cirm & 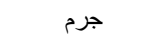 & Hacim \\
\hline Dekkê & 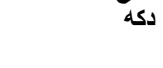 & Kulübe; küçük dükkân & Tekke & تكيه & $\begin{array}{l}\text { Tarikat mensuplarının yaşadığı, } \\
\text { ibadet ettiği dergâh }\end{array}$ \\
\hline Ehram & 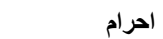 & Haramlar & İhram & احرام - ام & Hacı örtüsü \\
\hline Exbar & اخبار & Haberler & İhbar & اخبر & Haber verme \\
\hline Hac & 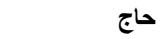 & Hacı & Hac & 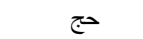 & Kâbe ziyareti \\
\hline Şaxês & شاخص & Belirgin, tanınmış, somut & Şahıs & شخص & Kişi \\
\hline Tabaq & طاباق & Büyük, kerpiç & Tabak & طبق & Derin olmayan kap \\
\hline Tabêq & تابق & Asa, değnek & Tabak & طبق & Derin olmayan kap \\
\hline Vaqêf & واقف & Duran, bekleyen & Vakıf & وقف & Vakıf \\
\hline Vasêf & واصف & Öven, anlatan & Vasıf & وصف & Nitelik \\
\hline Vehş & وحش & Doğa, doğal & Vahşi & 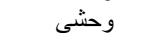 & Yirtici \\
\hline Xatim & خاتم & Son, bitiren & Hatim & ختم & Kur'an'ın tamamını okuma \\
\hline
\end{tabular}

\subsubsection{Farsça-Türkçe Dil İlişkisinde Fransızca-Fransızca Yalancı Kökteş Kelime Çiftleri}

Farsça-Türkçe dil ilişkisindeki Fransızca dil içi 1 yalancı kökteş kelime çifti tespit edilmiştir. Biri Farsçada, diğeri Türkçede kullanılmaktadır (Tablo 13).

\begin{tabular}{|l|c|}
\hline Ben mağazadan bir burs satın aldım. (Y) & من از فروشگَاه يك برس خريدم. \\
\hline Ben mağazadan bir saç firçası satın aldım. (D) & Men ez bazar yêk bors xeridem. \\
\hline
\end{tabular}


Farsçanın Türkiye'de Yabancı Dil Olarak Öğretiminde Yalancı Kökteşlik...

Örnek cümledeki Fransızca يرسbors kelimesi Farsçada saç firçası anlamındadır. Yalancı kökteşi Fransızca burs Türkçede ögrrenim ve araştırma için verilen maddi destek anlamındadır.

Tablo 13. Farsça-Türkçe Dil İlişkisinde Fransızca-Fransızca Yalancı Kökteş Kelimeler

\begin{tabular}{|c|c|c|c|c|}
\hline $\begin{array}{l}\text { Kelimenin } \\
\text { Farsça } \\
\text { Telaffuzu }\end{array}$ & $\begin{array}{l}\text { Kelimenin } \\
\text { Farsça } \\
\text { Yazılıșı }\end{array}$ & $\begin{array}{l}\text { Kelimenin Farsçadaki } \\
\text { Anlamı }\end{array}$ & $\begin{array}{l}\text { Kelimenin } \\
\text { Türkçe } \\
\text { Telaffuzu }\end{array}$ & Kelimenin Türkçedeki Anlamı \\
\hline Bors & برس & Saç firçası & Burs & $\begin{array}{l}\text { Öğrenim ve araştırma masrafi } \\
\text { için verilen destek }\end{array}$ \\
\hline
\end{tabular}

\section{Sonuç}

Yalancı kökteşler dil öğretiminin ve çevirinin önemli bir sorunudur. Hatasız bir çeviri ve sorunsuz bir dil öğretimi için iyi seviyede kaynak dil ve hedef dil bilgisinin yanı sıra dil bilinci, dikkat ve farkındalık da gereklidir.

Kaynak dil ve hedef dil çifti arasındaki ilişki düzeyi ve bu iki dilin çevre dillerle olan ilişkileri arttıkça yalancı kökteş kelime sayısı da artmaktadır.

Sağlıklı bir dil öğretim süreci için yalancı kökteş ve yalancı eş değer kelimelerin A1-A2 düzeylerinin sonrasına bırakılması faydalı olacaktrr.

Tespit edilen yalancı kökteşler basamaklı kur sisteminde anlam alanları itibariyle dil pasaportu çerçevesinde B1 ve üstü düzeylerde ihtiyaç duyulan kelimelerdir.

Dil kurslarının ikinci haftasında karşılaşılan medrese kelimesi A1 düzeyinde yaşanan soruna iyi bir örnek teşkil etmektedir.

Farsça öğrenicilerinin çoğunlukla lisans ve üstü düzeyler olmasından hareketle medresê kelimesi yerine danêşgah kelimesinin kullanılarak öğrenci ile yakın çevre arasındaki ilişkinin örneklendirilmesi daha faydalı olacaktır.

Farsça-Türkçe dil ilişkisindeki yalancı kökteşlik diller arası yalancı kökteşlik ve dil içi yalancı kökteşlik şeklinde iki gruba ayrılmaktadır.

Elde edilen veriler ve yapılan inceleme doğrultusunda bu gruplar çalı̧̧mada şu şekilde tasnif edilebilir:

$\mathrm{Bu}$ çalışmada tespit edilen yalancı kökteşlerin özellikleri itibariyle dört gruba ayrıldığı görülmüştür. Bunlar;

a) İki dil arasında kelime alışverişi olmadan, her iki dilin kendi söz varlı̆ı̆ındaki kelimelerin yalancı kökteş olmas1,

b) İki dil arasındaki ilişkide tespit edilen kelimelerden birinin incelemeye konu dillerden birinin kendi söz varlığından olması ve diğer kelimenin ise üçüncü bir dilden karşı dile geçerek yalancı kökteş olması,

c) Her iki dildeki kelimelerin kendi söz varlıklarından olmayıp üçüncü ve dördüncü yabancı dillerden bu dillere geçerek yalancı kökteş olması,

d) İncelemeye konu iki dilden biri kökenli bir kelimenin üçüncü yabancı dilden gelen bir kelimeyle yalancı kökteş kelime durumuna düşmüş olmasıdır.

İki dil ilişkisinde karşılaşılan yalancı kökteş kelimelerin söz konusu iki dilin söz varlığından olmasının gerekmediği, incelemeye konu olan dil çiftinin ayrı ayrı başka bir dilden ödünçlediği kelimelerde de yalancı kökteşlik durumunun oluştuğu görülmektedir.

Farsça-Türkçe dil ilişkisinde, Farş̧a ve Türkçe dışında Arapça, Fransızca, İngilizce, İtalyanca, Soğdca ve Yunanca olmak üzere altı yabancı dilden çok sayıda kelimenin ayrı ayrı her iki dile geçerek yalancı kökteşlik oluşturdukları görülmüştür. Bu çalışmada tespit edilen 175 diller arası yalancı kökteş kelime çiftinin 98 'i Farsça ve Türkçe kökenli iken 77'si de diğer dillerden her iki dile geçmiş ve yalancı kökteşlik oluşturmuş kelimelerdir.

Bu çalışmada tespit edilen 175 diller arası yalancı kökteş kelime çiftinin 98'inin Farsça ve Türkçe kökenli, 77'sinin diğer dillerden her iki dile geçmiş ve yalancı kökteşlik oluşturmuş kelimeler olduğu görülmüştür. Farsça-Türkçe dil ilişkisinde karşılaşılan 215 diller arası yalancı kökteş kelime çiftinin 98'inin Farsça-Türkçe kökenli, 22'sinin Farsça-Arapça kökenli, 11'inin Arapça-Türkçe kökenli, 25'inin Farsça-Fransızca kökenli, 4'ünün Türkçe-Fransızca, 4'ünün Farsça-İtalyanca kökenli, 2'sinin Fransızca-Yunanca kökenli, birer kelimenin de Farsça-Soğdca ve Fransızca-İngilizce kökenli olduğu görülmüştür.

Farsça-Türkçe dil ilişkisindeki 20'si Farsça, 48'in Arapça 68 dil içi yalancı kökteş kelime çifti tespit edilmiştir. Farsça-Türkçe dil ilişkisinde 10 Farsça, 22 Arapça, 1 Fransızca kelime çifti tespit edilmiştir. 


\section{Kaynaklar}

Aksan, D. (2016). Anlambilim: Anlambilim Konuları ve Türkçenin Anlambilimi. Ankara: Bilgi.

Bermaganbetova, S. (2016). Türkiye Türkçesi ve Kazak Türkçesi Arasındaki Yalancı Eş Değerler. İzmir: Dokuz Eylül Üniversitesi, Yüksek Lisans Tezi.

Çelik, A. (2005). Tanzimat'tan Günümüze Türkiye’de Farsça Öğretimi. Doktora Tezi, İstanbul: İstanbul Üniversitesi.

Dilberipur, A. (1995). Türkçe-Farsça ortak Kelimeler Sözlüğü. Ankara.

Dursunoğlu, H. (2009). Türkiye Türkçesindeki Farsça Sözcükler ve Kullanım Şekilleri. Atatürk Üniversitesi Sosyal Bilimler Enstitüsü Dergisi 13 (1): 131-142.

Erkır, B. (2011). Yabancı Dil Olarak Türkçe Öğretiminde Karşılaştırmalı Türkçe-Ingilizce Sözde Denkteşler (False Cognates) Listesinin Oluşturulması ve Bu Listenin Eğitbilimsel Olarak Kullanılmast. Yüksek Lisans Tezi, İzmir: Dokuz Eylül Üniversitesi.

MEB, Yabancı Dil Ĕgitimi ve Öğretimi ile Türk Vatandaşlarının Farklı Dil ve Lehçelerinin Öğrenilmesi Hakkında Kanun, https://www.mevzuat.gov.tr/MevzuatMetin/1.5.2923.pdf Erişim Tarihi: 18.08.2021.

Özeren, M. (2014). Salar Türkçesi ve Türkiye Türkçesi Arasındaki Yalancı Eşdeğer Sözcükler. TEKE, 3/2, 111-127.

Ozeren, M. (2017). O Lojnıh Ekvivalentah Rodstvennogo Proishojdeniya v Altayskom i Turetskom Yazıkah. Yazık i Literatura, 4(104), Bak1 2017, s. 278-280.)

Ozeren, M., Abdieva, R. (2018). O lojnıh ekvivalentah rodstvennogo proishojdeniya v kırgızskom i turetskom yazıkah. Tanrı Dağlarının Anadolu'daki Illk Profesör Kızı Gülzura Cumakunova (Ed. A. İsakov-G. Murzakulova), Bengü Yay., Ankara, s. 107-116.)

Ozeren, M. (2019). Lojnıe Ekvivalentı / False Equivalents. Problemı Sovremennoy Nauki i Obrazovaniya / Problems of Modern Science and Education. No. 1 (134), 2019, s. 75-78. (https://ipi1.ru/images/2019/134/PMSE-1-134.pdf)

Pirooz, M. R. (2003). On English-Persian and Persian-English False Cognates. Iranian Journal Of Applied Linguistics (IJAL), İran: Sistan-Belucestan, 6-1, 118-136.

Resulov, A. (1995). Akraba Diller ve Yalancı Eş Değerler Sorunu. Türk Dili 524, 916-924, Ankara.

Söylemez, İ. (2021). Türkiye'de Yabancı Dil Olarak Farsça Öğretiminde Yalancı Eş Değerlik (İran Farsçası ve Türkiye Türkçesi Örneklemi). Nüsha 53, 243-296, Ankara.

Şimşekler, N. (2021). Türkiye'nin Bir İhtiyacı: İran, Afganistan ve Tacikistan Farsçasını Kapsayan Farsça Mütercim-Tercümanlık Bölümü. Afganistan-İran-Tacikistan Dil ve Edebiyat Yazllarl, (Ed. İsmail Söylemez) 33-38, İstanbul: Demavend.

Turgut, K. (2011). Türkiye'de Farsça Dili ve Edebiyatı Alanında Yapılan Çalışmalar Bibliyografyası Denemesi I: Fars Dili ve Edebiyatı Anabilim Dallarında Hazırlanan Doktora ve Yüksek Lisans Tezleri. Şarkiyat Mecmuast, İstanbul.

Türkben Aydın, F. (2018). Dil Öğreniminde Türkçe-Farsça Ortak Deyimlerin Önemi Üzerine Bir İnceleme. Turkish Studies, S.13/4, Ankara.

Uzun, L. ve Salihoğlu (2009). English-Turkish Cognates and False Cognates: compiling a Corpus and Testing How They ara Translated by Computer Programs. Poznan Studies in Contemporary Linguistic 45 (4)., 569-593.

\section{Etik, Beyan ve Açıklamalar}

\section{Etik, Beyan ve Açılamalar}

\section{Etik Kurul izni ile ilgili;}

『 Bu çalışmanın yazar/yazarları, Etik Kurul İznine gerek olmadığını beyan etmektedir.

2. Bu çalışmanın yazar/yazarları, araştırma ve yayın etiği ilkelerine uyduklarını kabul etmektedir.

3. Bu çalışmanın yazar/yazarları kullanmış oldukları resim, şekil, fotoğraf ve benzeri belgelerin kullanımında tüm sorumlulukları kabul etmektedir.

4. Bu çalışmanın benzerlik raporu bulunmaktadır. 